sativa and $M$. falcata and their history in East Anglia" and shows that M. sylvestris is of hybrid origin. Other articles include "The Adventive Flora of the Port of Bristol" by C. I. Sandwith, "Plant Nomenclature" by Dr. Sprague, and a well-illustrated account of environmental adaptation in various sand dune plants at Braunton Burrows by Dr. F. R. E. Wright.

\section{Australian Entomology}

INTEREST in the remarkable insect fauna of Australia began to be taken soon after Capt. Cook reached the continent in 1770 . There has since arisen an increasing number of writings on Australian insect life. Of late, the stimulus given by applied entomology has led to a great and important literature on the insect pests of the economic animals and plants of the continent. In September 1932, a "Bibliography of Australian Entomology, 1775-1930", by Mr. Anthony Musgrave, was published by the Royal Zoological Society of New South Wales. In his capacity as entomologist to the Australian Museum, Sydney, Mr. Musgrave has listed the title of every known book, memoir and article bearing upon the subject. These are arranged under the authors' names, which are set out alphabetically. A feature of special interest is the series of biographical notes on many of the writers and collectors who have helped to build up our knowledge of Australian entomology. In the production of this bibliography, which runs to 380 closely printed pages, both the author and the Society have conferred a boon on entomologists throughout the world.

\section{Hydrographical Observations from Danish Light-Vessels}

THE recently published "Mean Values of Observations from Danish Light-Vessels" is a pamphlet issued as a special reprint from the Nautical Meteorological Annual, 1932, of the Danish Meteorological Institute. There are numerous tables summarising observations made at Danish light-vessels, such as the salinity at 8 a.m. of the sea-water at the surface and at various depths down to the ocean bottom, frequencies of horizontal visibility of the atmosphere between certain limits in miles, and frequency of ocean currents of various velocities, at different depths of the ocean. These are all long-period averages, mostly referring to $1901-30$ or $1903-30$, but for sea surface temperature going back to 1881, and for visibility beginning only in 1918, when the modern system of measuring visibility was introduced, and extending only to 1927 . This is clearly not a work for the ordinary student of meteorological literature, but one for the specialist in hydrographic work and for the sailor, and even to those it must be mainly a work of reference. The number of individual observations on which it is based is very large, and the statistical value of the averages is proportionately great.

\section{Revision of Ordnance Maps}

IN the report of the Progress of the Ordnance Survey for the year 1932-33 (London: H.M.
Stationery Office, $1933.3 s .6 d$. net), attention is directed to the difficulties and delay in revision of the sheets owing to financial restrictions. The reduced staff available for field work on large-scale plans means that revision has to be limited, more and more, to areas completely altered or built over since the last edition of the sheet. Field work thus tends to become original survey and the time needed for each sheet increases. While the yearly output of 25 -in. plans was more than two thousand in 1923, it has now fallen to about seven hundred. In the earlier year the number of man-days spent in the field upon the revision of one 25 -in. sheet was about eleven; it is now about fifty-two. The delay is thus progressive as time goes on, and has already become very serious. Since the revision for the one-inch sheet is based on large-scale plans, the new edition of small-scale maps is seriously impeded. Whereas in 1913 a one-inch reviser could do 96 square miles per month in open country or 40 square miles in close country, he can now do only 18 per month in country round London. Nevertheless, the new relief edition of the one-inch map is making steady if slow progress.

\section{Water Flow of the Nile}

Two further volumes of the Egyptian Government's work on the Nile Basin have been published ("The Nile Basin". By H. E. Hurst and P. Phillips. Vols. 3 and 4. Cairo: Government Press. 10s. each). Vol. 3 deals with the gauge readings of the Nile and its tributaries taken at about a hundred stations between El Leisi, a few miles above Cairo, to stations on Lake Victoria and Lake Albert. Most of the data begin within this century, but it is of interest to note that on Roda Island the Nile levels have been recorded each year since the Arab conquest of Egypt. Records of other Arab nilometres are also known but are of little value as their relation to present levels cannot be determined. Vol. 4 records ten-day and mean monthly discharges of the Nile and tributaries at about forty stations, which have been computed in various ways.

\section{The 'Iconoscope' for Television}

An article under this title appeared in Nature of October 21, p. 648. A paper by Dr. V. K. Zworykin has now appeared in Great Britain $(J$. Inst. Elect. Eng., No. 432). He describes clearly the theory, characteristics and mode of operation of his system, which has now reached the commercial stage. The device used for the registration of the image is calied an 'iconoscope'. It consists of a vacuum tube, an electron-emitting 'gun' and a photo-sensitive surface of a unique type. This surface is scanned by an electron beam from the gun which serves as a type of inertialess commutator. The principle of operation permits the storing of energy and very largely increases the output as compared with the ordinary types of television scanners. The reproduction of the image is accomplished by another cathode ray tube with a fluorescent screen called the 'kinescope'. It modulates the impulses from the 